\title{
Analisis Efisiensi Model Economic Order Quantity (EOQ) Pada CV. Rafhanah
}

\author{
Santika Sari ${ }^{1}$, Cindy Meisya Putri Hidayat ${ }^{2}$, Muhammad Rizal $^{3}$, Dinda Tria Pratiwi ${ }^{4}$, \\ Wira $\mathrm{Ayu}^{5}$, Akhmad Nidhomuz Zaman ${ }^{6}$ \\ e-mail : santika.sari@upnvj.ac.id, akhmadnidhomuzzaman@upnvj.ac.id \\ 1,2,3,4,5,6 Teknik Industri, Fakultas Teknik \\ Universitas Pembangunan Nasional Veteran Jakarta, Indonesia
}

\begin{abstract}
ABSTRAK
Salah satu permasalahan yang sering dihadapi oleh perusahaan adalah mengenai pengolahan persediaan bahan baku yang baik. Jumlah persediaan yang terlalu besar akan mengakibatkan timbulnya dana yang dikeluarkan menjadi terlalu besar, selain itu resiko kerusakan barang juga menjadi lebih besar. Namun bila persediaan terlalu sedikit akan mengakibatkan terjadinya kekurangan persediaan yang dapat menyebabkan hilangnya keuntungan. Penelitian dibuat untuk mengetahui perbandingan efisiensi manajemen persediaan yang dilakukan oleh CV. Rafhanah dengan manajemen persediaan metode model Economic Order Quantity (EOQ). Pengumpulan data berupa laporan persediaan yang terkait dengan harga bahan, jumlah persediaan bahan, biaya pesan dan biaya simpan persediaan bahan periode tahun 2018 . Hasil penelitian ini menunjukkan bahwa total biaya persediaan yang harus dikeluarkan oleh CV. Rafhanah untuk periode 2018 sebesar Rp 41.124.850,00 sedangkan hasil perhitungan pada model EOQ, total biaya persediaan hanya sebesar $\mathrm{Rp}$ 29.132.382,00. Sehingga penerapan model EOQ pada manajemen persediaan CV. Rafhanah menghasilkan penghematan biaya persediaan sebesar Rp 11.992.467,00 atau lebih efisien sebesar 29\%. Semua komponen persediaan pada CV. Rafhanah dapat dihitung menggunakan model EOQ dikarenakan semua jenis komponen yang terdapat dalam produk tersebut dapat bertahan lama dan dapat disimpan dalam waktu yang lama.
\end{abstract}

Kata kunci: bahan baku, efisiensi, EOQ, perbandingan, persediaan, stok

\section{PENDAHULUAN}

Pengembangan suatu model persediaan dalam beberapa tahun terakhir mengalami ketidaksesuaian karena kemunduran suatu barang. Hal tersebut yang menyebabkan kerugian karena kerusakan di bidang inventaris tidak dapat diabaikan, diketahui bahwa tingkat stok memiliki efek motivasi pada pelanggan di pasar, yaitu permintaan dengan nilai dapat naik atau turun jika tingkat persediaan di tangan meningkat atau menurun. Situasi seperti itu umumnya muncul untuk jenis persediaan barang konsumen. Maka memungkinkan untuk memesan dalam jumlah besar sehingga sisa persediaan pada akhir siklus berpotensi mengalami keuntungan yang diperoleh dari peningkatan permintaan (Mishra and Mishra 2008). Kebijakan dari pemasok yang berupaya memenuhi permintaan yang diberikan untuk produk yang sama. Unit produk diterima dari sebuah pabrik dalam batch dan disimpan di gudang sebelum dikirim ke pelanggan. Satu unit produk diasumsikan diminta dalam setiap interval satuan waktu. Oleh karena itu, panjang perencanaan (jumlah total interval unittime) sama dengan permintaan. Ketika stok produk di gudang habis ke nol, maka kembali diisi kembali dengan menerima batch baru (Ng et al. 2009).
Salah satu permasalahan yang sering dihadapi oleh perusahaan adalah mengenai pengolahan persediaan bahan baku yang baik. Jumlah persediaan yang terlalu besar mengakibatkan timbulnya dana yang dikeluarkan menjadi terlalu besar, selain iturisi ko kerusakan barang juga menjadi lebih besar. Namun bila persediaan terlalu sedikit akan mengakibatkan terjadinya kekurangan persediaan yang dapat menyebabkan hilangnya keuntungan (Naibaho n.d.). Untuk itu perusahaan melakukan pengawasan atas persediaan. Kegiatan ini dapat membantu tercapainya suatu tingkat efisiensi penggunaan dalam persediaan. Dengan adanya kebijakan persediaan bahan yang diterapkan dalam perusahaan, kekurangan bahan dalam proses produksi dan biaya persediaan dapat ditekan sekecil mungkin. Metode EOQ berusaha mencapai tingkat persediaan yang seminimum mungkin, biaya rendah dan mutu yang lebih baik. Perencanaan. Metode EOQ dalam suatu perusahaan akan mampu meminimalisasi terjadinya outofstock sehingga tidak mengganggu proses produksi dalam perusahaan dan mampu menghemat biaya persediaan yang dikeluarkan oleh perusahaan karena adanya efisiensi persediaan bahan baku dalam perusahaan (Suryanto 2012). 
Model persediaan EOQ merupakan dasar backorder telah dikembangkan dari berbagai perspektif oleh beberapa peneliti. Namun, belum bisa membuktikan solusi yang optimal belum lengkap (Chung and Cárdenas-Barrón 2012). Model EOQ untuk singgle item dengan backorder yang terencana, menunjukkan bahwa EOQ dapat membuat pemikiran yang ekonomis dengan asumsi bahwa pelanggan bersedia menunggu (Godichaud and Amodeo 2019)

Obyek penelitian ini adalah CV.Rafhanah yang merupakan perusahaan yang bergerak dibidang garment retail busana muslim misalnya gamis, hijab, dan lain lainnya. Bertempat di Thamrin City, Jakarta Pusat. Masalah yang sering terjadi diperusahaan tersebut adalah ketidak pastiannya permintaan, ketidak pastian pekerja,dan ketidak pastian jumlah produksi. Maka jumlah persediaan terkadang melebihi jumlah permintaan konsumen sehingga menghambat pertumbuhan perusahaan untuk menciptakan model model yang diminati oleh konsumen dan penumpukan pada persediaan. Dan perusahaan ini mempunyai masalah pada kondisi jumlah persediaan bahan baku mendekati stockout yang disebabkan adanya ketidak pastian jumlah pembelian dan keterlambatan dalam pemesanan.

Untuk menentukan kebijakan penyediaan bahan yang tepat dalam arti tidak mengganggu proses produksi dapat dipakai metode EOQ, yaitu jumlah kuantitas bahan yang dapat diperoleh dengan biaya yang minimal setiap kali pembelian. Banyak model persediaan dalam manajemen Supply chain didasarkan pada model EOQ atau EPQ karena kesederhanaan penggunaan serta keandalan (Omar, Bakri Zubir, and Moin 2010). Tujuan dari penelitian ini adalah untuk efisiensi manajemen persediaan yang dilakukan oleh CV.Rafhanah dibandingkan dengan manajemen persediaan model EOQ. Diharapkan dengan hasil perbandingan, bisa menjadi bahan pertimbangan perusahaan untuk manajemen persediaa.

\section{METODE PENELITIAN}

Pada penelitian ini tedapat proses dalam EOQ adalah dengan memberikan gambaran mengenai perbandingan biaya yang diterapkan perusahaaan dengan manajemen persediaan model EOQ. Tahap pertama adalah pengumpulan data meliputi Rekapitulasi persediaan CV.Rafhanah periode 2018, data biaya pesan dan simpan.
Tahap kedua adalah proses EOQ yaitu perhitungan persediaan, menghitung pesanan optimum, perhitungan biaya simpan optimum, total biaya optimum persediaan, jarak siklus, stok pengaman, pemesanan kembali, dan tahap perbandingan EOQ dengan perusahaan.

Pengumpulan data meliputi data rekapitulasi bahan baku produk pada periode tahun 2018 (tabel 1), biaya simpan, pemesanan, dan total persediaan.

Tabel 1. Rekapitulasi Persediaan Bahan Baku

\begin{tabular}{|c|l|r|r|r|r|c|}
\hline No & Part & $\begin{array}{c}\text { Kebutu } \\
\text { han } \\
\text { Rata- } \\
\text { rata }\end{array}$ & $\begin{array}{c}\text { Harga } \\
\text { Rata- } \\
\text { rata }\end{array}$ & $\begin{array}{c}\text { Biaya } \\
\text { Pesan } \\
\text { per } \\
\text { Order } \\
\text { (Rp) }\end{array}$ & $\begin{array}{c}\text { Biaya } \\
\text { Simpan } \\
\text { per } \\
\text { Unit } \\
\text { (Rp) }\end{array}$ & $\begin{array}{c}\text { Freku } \\
\text { ensi }\end{array}$ \\
\hline 1 & Kain & 14000 & 30.000 & 600.000 & 1800 & 22 \\
\hline 2 & $\begin{array}{l}\text { Bordir } \\
\text { Logo } \\
\text { kecil }\end{array}$ & 4050 & 2.500 & 50.000 & 150 & 8 \\
\hline 3 & $\begin{array}{l}\text { Reseleti } \\
\text { ng }\end{array}$ & 1250 & 1.500 & 50.000 & 90 & 9 \\
\hline 4 & $\begin{array}{l}\text { Hantag } \\
\text { hitam }\end{array}$ & 4035 & 500 & 30.000 & 30 & 8 \\
\hline 5 & Label & 4100 & 300 & 30.000 & 18 & 8 \\
\hline 6 & $\begin{array}{l}\text { Plastik } \\
\text { opp } \\
\text { besar }\end{array}$ & 4500 & 1.000 & 30.000 & 60 & 7 \\
\hline
\end{tabular}

Pada Tabel 2. Data Biaya Simpan, Pemesanan, dan Total Persediaan

\begin{tabular}{|c|l|r|r|r|}
\hline No. & \multicolumn{1}{|c|}{ Part } & \multicolumn{1}{c|}{$\begin{array}{c}\text { Biaya } \\
\text { Simpan }\end{array}$} & $\begin{array}{c}\text { Biaya } \\
\text { Pemesanan }\end{array}$ & $\begin{array}{c}\text { Total } \\
\text { Persediaan }\end{array}$ \\
\hline 1 & Kain & 13200000 & 25200000 & 38400000 \\
\hline 2 & $\begin{array}{l}\text { Bordir Logo } \\
\text { kecil }\end{array}$ & 400000 & 607500 & 1007500 \\
\hline 3 & Reseleting & 450000 & 112500 & 562500 \\
\hline 4 & $\begin{array}{l}\text { Hantag } \\
\text { hitam }\end{array}$ & 240000 & 121050 & 361050 \\
\hline 5 & Label & 240000 & 73800 & 313800 \\
\hline 6 & $\begin{array}{l}\text { Plastik opp } \\
\text { besar }\end{array}$ & 210000 & 270000 & 480000 \\
\hline \multicolumn{2}{|r|}{ Total (Rp) } & 14740000 & 26384850 & 41124850 \\
\hline
\end{tabular}

Pada tabel 2 merupakan hasil total persediaan yang berasal dari penjumlahan anatara biaya pesan dan biaya simpan pada CV.Rafhanah periode 2018 sebersar Rp.41.124.850.

\section{HASIL DAN PEMBAHASAN}

Hasil perhitungan EOQ pada tabel 3 adalah hasil yang paling ekonomis yang harus dilakukan oleh CV.Rafhanah dalam setiap kali melakukan pemesanan, dari hasil perhitungan tersebut perusahaan akan memperoleh efisiensi baik dari segi jumlah persediaan maupun dari segi jumlah biaya yang harus dikeluarkan. 
Tabel 3. Perhitungan EOQ CV.Rafhanah Periode 2018

\begin{tabular}{|l|l|l|l|l|l|c|}
\hline No & Part & $\begin{array}{c}\text { Kebut } \\
\text { uhan } \\
\text { Rata- } \\
\text { rata/ } \\
\text { tahun }\end{array}$ & $\begin{array}{c}\text { Biaya } \\
\text { pesan } \\
\text { per } \\
\text { order } \\
\text { (Rp) }\end{array}$ & $\begin{array}{c}\text { Biaya } \\
\text { Simpa } \\
\text { nper } \\
\text { unit } \\
\text { (Rp) }\end{array}$ & EOQ & $\begin{array}{c}\text { Freku } \\
\text { ensi }\end{array}$ \\
\hline 1 & Kain & 14000 & $\begin{array}{l}600.00 \\
0\end{array}$ & 1.800 & $\begin{array}{l}3055.0 \\
50463\end{array}$ & 5 \\
\hline 2 & $\begin{array}{l}\text { Bordir } \\
\text { Logo } \\
\text { kecil }\end{array}$ & 4050 & 50.000 & 150 & $\begin{array}{l}1643.1 \\
67673\end{array}$ & 3 \\
\hline 3 & $\begin{array}{l}\text { Resele } \\
\text { ting }\end{array}$ & 1250 & 50.000 & 90 & $\begin{array}{l}1178.5 \\
11302\end{array}$ & 2 \\
\hline 4 & $\begin{array}{l}\text { Hanta } \\
\text { g } \\
\text { hitam }\end{array}$ & 4035 & 30.000 & 30 & $\begin{array}{l}2840.7 \\
74542\end{array}$ & 2 \\
\hline 5 & Label & 4100 & 30.000 & 18 & $\begin{array}{l}3696.8 \\
45502\end{array}$ & 2 \\
\hline 6 & $\begin{array}{l}\text { Plastik } \\
\text { opp } \\
\text { besar }\end{array}$ & 4500 & 30.000 & 60 & $\begin{array}{l}2121.3 \\
20344\end{array}$ & 3 \\
\hline
\end{tabular}

Contoh Tabel 3 pada part untuk Frekuensi pemesanan yang paling ekonomis adalah 5 kali dalam pemesanan kain bordir dengan EOQ sebesar 3055.050463. Jumlah persediaan harus dikendalikan sehingga jumlahnya tidak terlalu besar dan terlalu sedikit tapi optimal. Jumlah persediaan yg optimal menyebabkan biaya persediaan juga menjadi optimal. Biaya persediaan terdiri dari biaya pesan dan biaya simpan. Berikut biaya optimum menggunakan metode EOQ.

Tabel 4. Biaya Optimum berdasarkan EOQ

\begin{tabular}{|l|c|}
\hline \multicolumn{1}{|c|}{ Part } & Jumlah \\
\hline Kain & 3055.050463 \\
\hline Bordir Logo kecil & 1643.167673 \\
\hline Reseleting & 1178.511302 \\
\hline Hantag hitam & 2840.774542 \\
\hline Label & 3696.845502 \\
\hline Plastik opp besar & 2121.320344 \\
\hline
\end{tabular}

Jumlah pesanan masing-masing bahan baku pada tabel 4 yang paling optimal. Pada jumlah tersebut CV.Rafhanah memperoleh hasil yang paling efisien karena jumlah pemesanan benarbenar sesuai dengan kebutuhan dalam setiap periodenya.

Tabel 5. Biaya Optimum Pesan, Persediaan dan Simpan

\begin{tabular}{|c|c|c|c|}
\hline Part & $\begin{array}{l}\text { Biaya } \\
\text { Optimum } \\
\text { Pesan }\end{array}$ & $\begin{array}{c}\text { Biaya } \\
\text { Optimum } \\
\text { Simpan }\end{array}$ & $\begin{array}{c}\text { Biaya } \\
\text { Optimum } \\
\text { Persediaan }\end{array}$ \\
\hline Kain & $\begin{array}{r}13747727 . \\
08\end{array}$ & $\begin{array}{r}13747727.0 \\
8\end{array}$ & 27495454.17 \\
\hline $\begin{array}{l}\text { Bordir Logo } \\
\text { kecil }\end{array}$ & $\begin{array}{r}369712.72 \\
63\end{array}$ & $\begin{array}{r}369712.726 \\
3\end{array}$ & 739425.4526 \\
\hline Reseleting & $\begin{array}{r}106066.01 \\
72\end{array}$ & 106066.017 & 212132.0344 \\
\hline $\begin{array}{l}\text { Hantag } \\
\text { hitam }\end{array}$ & $\begin{array}{r}85223.236 \\
27\end{array}$ & $\begin{array}{r}85223.2362 \\
7\end{array}$ & 170446.4725 \\
\hline Label & $\begin{array}{r}66543.219 \\
04\end{array}$ & $\begin{array}{r}66543.2190 \\
4\end{array}$ & 133086.4381 \\
\hline $\begin{array}{l}\text { Plastik opp } \\
\text { besar }\end{array}$ & $\begin{array}{r}190918.83 \\
09\end{array}$ & $\begin{array}{r}190918.830 \\
9\end{array}$ & 381837.6618 \\
\hline Total & $\begin{array}{r}14566191 . \\
11\end{array}$ & $\begin{array}{r}14566191.1 \\
1\end{array}$ & 29132382.23 \\
\hline
\end{tabular}

Jumlah biaya pesan berdasarkan EOQ dapat dilihat pada tabel 5, hasil tersebut didapatkan dari jumlah keutuhan rata-rata dibagi dengan demand EOQ dikalikan dengan biaya pesan. Didapatkan total biaya sebesar RP.14.566.191. Pada Jumlah biaya simpan berdasarkan EOQ, hasil tersebut didapatkan dari biaya optimum EOQ dibagi dua dikalikan dengan biaya simpan. Didapatkan total biaya sebesar RP.14.566.191. Data biaya persediaan merupakan biaya total persediaan masing-masing komponen dengan model EOQ, Biaya tersebut merupakan biaya minimum yang harus dikeluarkan oleh perusahaan untuk pemesanan tiap komponen atau penyimpanan bahan dalam satu tahun periode sebesar Rp.29.132.382,23.

Tabel 6. Waktu Siklus Perusahaan

\begin{tabular}{|l|r|}
\hline \multicolumn{1}{|c|}{ Part } & \multicolumn{1}{c|}{ Waktu Siklus } \\
\hline Kain & 73 \\
\hline Bordir Logo kecil & 122 \\
\hline Reseleting & 183 \\
\hline Hantag hitam & 183 \\
\hline Label & 183 \\
\hline Plastik opp besar & 122 \\
\hline
\end{tabular}

Pada tabel 6 adalah jarak siklus (waktu) perusahaan. Pada tebel 7 Safety Stock diperlukan untuk mengurangi kerugian yang ditimbulkan karena terjadinya stock out oleh karena itu perusahaan perlu mengadakan perhitungan untuk menentukan safety stock yang paling optimal.

Tabel 7. Safety Stock (SS) Perusahaan Periode 2018

\begin{tabular}{|l|r|}
\hline \multicolumn{1}{|c|}{ Part } & \multicolumn{1}{c|}{ SS } \\
\hline Kain & 1333.333 \\
\hline Bordir Logo kecil & 625 \\
\hline Reseleting & 158.3333 \\
\hline Hantag hitam & 1137.5 \\
\hline Label & 1083.333 \\
\hline Plastik opp besar & 890 \\
\hline
\end{tabular}

Pada tabel 8 Saat pemesanan kembali (reorder point/ROP) adalah saat dimana perusahaan harus melakukan pemesanan bahan bakunya kembali, sehingga penerimaan bahan baku yang dipesan dapat tepat waktu. Perusahaan memiliki lead time 10 hari, oleh karena itu ROP dirumuskan sebagai berikut; ROP $=10 \mathrm{x}$ $(\mathrm{EOQ} / 365)+$ Safety Stock.

Tabel 8. Reorder Point (RP)

\begin{tabular}{|l|c|}
\hline \multicolumn{1}{|c|}{ Part } & RP \\
\hline Kain & 1417.0333 \\
\hline Bordir Logo kecil & 670.01829 \\
\hline Reseleting & 190.62131 \\
\hline Hantag hitam & 1215.3294 \\
\hline Label & 1184.6168 \\
\hline Plastik opp besar & 948.11837 \\
\hline
\end{tabular}

Perbandingan sebelum dan setelah penggunaan model EOQ dalam manajemen 
persediaan dimaksudkan agar perusahaan dapat mengetahui efektifitas dan efisiensi kebijakan menejemen persediaan yang telah ditetapkan oleh perusahaan (tabel 9).

Tabel 9. Perbandingan Persediaan Optimum CV.Rafhanah periode 2018

\begin{tabular}{|c|c|c|c|c|}
\hline No & Part & $\begin{array}{c}\text { Kebijakan } \\
\text { Perusahaan }\end{array}$ & EOQ & Selisih \\
\hline 1 & Kain & $\begin{array}{r}636.363636 \\
4\end{array}$ & $\begin{array}{r}3055.0504 \\
63\end{array}$ & $\begin{array}{r}2418.68 \\
6827 \\
\end{array}$ \\
\hline 2 & $\begin{array}{l}\text { Bordir Logo } \\
\text { kecil }\end{array}$ & 506.25 & $\begin{array}{r}1643.1676 \\
73\end{array}$ & $\begin{array}{r}1136.91 \\
7673 \\
\end{array}$ \\
\hline 3 & Reseleting & $\begin{array}{r}138.888888 \\
9\end{array}$ & $\begin{array}{r}1178.5113 \\
02\end{array}$ & $\begin{array}{r}1039.62 \\
2413 \\
\end{array}$ \\
\hline 4 & $\begin{array}{l}\text { Hantag } \\
\text { hitam }\end{array}$ & 504.375 & $\begin{array}{r}2840.7745 \\
42 \\
\end{array}$ & $\begin{array}{r}2336.39 \\
9542 \\
\end{array}$ \\
\hline 5 & Label & 512.5 & $\begin{array}{r}3696.8455 \\
02 \\
\end{array}$ & $\begin{array}{r}3184.34 \\
5502 \\
\end{array}$ \\
\hline 6 & $\begin{array}{l}\text { Plastik opp } \\
\text { besar }\end{array}$ & $\begin{array}{r}642.857142 \\
9\end{array}$ & $\begin{array}{r}2121.3203 \\
44\end{array}$ & $\begin{array}{r}1478.46 \\
3201 \\
\end{array}$ \\
\hline
\end{tabular}

Pada tabel 9 terdapat perbedaan yang cukup signifikan antara jumlah masing-masing persediaan bahan yang dipesan per order, antara model EOQ dan kebijakan yang ditetapkan oleh perusahaan. Misalnya kain terdapat selisih sebanyak 2418,68 yard.

Tabel 10. Perbandingan Biaya Pesan CV.Rafhanah periode 2018

\begin{tabular}{|c|l|c|c|c|}
\hline No & Part & $\begin{array}{c}\text { Kebijakan } \\
\text { Perusahaa } \\
\mathbf{n}\end{array}$ & EOQ & Selisih \\
\hline 1 & Kain & 13200000 & 13747727.08 & -547727.0849 \\
\hline 2 & $\begin{array}{l}\text { Bordir } \\
\text { Logo } \\
\text { kecil }\end{array}$ & 400000 & 369712.7263 & 30287.27368 \\
\hline 3 & $\begin{array}{l}\text { Resele } \\
\text { ting }\end{array}$ & 4500000 & 106066.0172 & 343933.9828 \\
\hline 4 & $\begin{array}{l}\text { Hanta } \\
\text { g } \\
\text { hitam }\end{array}$ & 2400000 & 85223.23627 & 154776.7637 \\
\hline 5 & Label & 2400000 & 66543.21904 & 173456.781 \\
\hline 6 & $\begin{array}{l}\text { Plasti } \\
\text { k opp } \\
\text { besar }\end{array}$ & 2100000 & 190918.8309 & 19081.16908 \\
\hline
\end{tabular}

Dari tabel 10 dapat diketahui bahwa secara keseluruhan biaya pesan dengan model EOQ jauh lebih rendah dari biaya pesan kebijakan perusahaan, walaupun untuk biaya tertentu pada kebijakan perusahaan nilai nominalnya lebih rendah. Pada biaya pesan Resleting lebih rendah Rp.343.933,98, dan Plastik lebih rendah Rp.19.081,16.
Tabel 11. Perbandingan Biaya Simpan CV.Rafhanah periode 2018

\begin{tabular}{|c|l|r|r|c|}
\hline No & Part & $\begin{array}{c}\text { Kebijakan } \\
\text { Perusahaan }\end{array}$ & EOQ & Selisih \\
\hline 1 & Kain & 25200000 & $\begin{array}{r}13747727.0 \\
8\end{array}$ & 11452272.92 \\
\hline 2 & $\begin{array}{l}\text { Bordir } \\
\text { Logo } \\
\text { kecil }\end{array}$ & 607500 & $\begin{array}{r}369712.726 \\
3\end{array}$ & 237787.2737 \\
\hline 3 & $\begin{array}{l}\text { Resele } \\
\text { ting }\end{array}$ & 112500 & $\begin{array}{r}106066.017 \\
2\end{array}$ & 6433.982822 \\
\hline 4 & $\begin{array}{l}\text { Hantag } \\
\text { hitam }\end{array}$ & 121050 & $\begin{array}{r}85223.2362 \\
7\end{array}$ & 35826.76373 \\
\hline 5 & Label & 73800 & $\begin{array}{r}66543.2190 \\
4\end{array}$ & 7256.780962 \\
\hline 6 & $\begin{array}{l}\text { Plastik } \\
\text { opp } \\
\text { besar }\end{array}$ & 270000 & $\begin{array}{r}190918.830 \\
9\end{array}$ & 79081.16908 \\
\hline & & 26384850 & 14566191.1 & 11818658.89 \\
\hline
\end{tabular}

Dari tabel 11 dapat diketahui bahwa secara keseluruhan biaya pesan dengan model EOQ jauh lebih rendah dari biaya pesan kebijakan perusahaan. Misalnya pada biaya pesan Resleting lebih rendah Rp.6.433,98. Perbedaan jumlah biaya pesan dan biaya simpan yang dihitung dengan model EOQ dan kebijakan perusahaan akan mempengaruhi total biaya persediaan yang perbandingannya dapat dilihat pada tabel 12:

Tabel 12. Perbandingan Total Persediaan CV.Rafhanah periode 2018
\begin{tabular}{|c|l|r|c|c|}
\hline No & Part & $\begin{array}{c}\text { Kebijakan } \\
\text { Perusahaan }\end{array}$ & EOQ & Selisih \\
\hline 1 & Kain & 38400000 & 27495454.17 & 10904545.83 \\
\hline 2 & $\begin{array}{l}\text { Bordi } \\
\text { r } \\
\text { Logo } \\
\text { kecil }\end{array}$ & 1007500 & 739425.4526 & 268074.5474 \\
\hline 3 & $\begin{array}{l}\text { Resel } \\
\text { eting }\end{array}$ & 562500 & 212132.0344 & 350367.9656 \\
\hline 4 & $\begin{array}{l}\text { Hanta } \\
\text { g } \\
\text { hitam }\end{array}$ & 361050 & 170446.4725 & 190603.5275 \\
\hline 5 & Label & 313800 & 133086.4381 & 180713.5619 \\
\hline 6 & $\begin{array}{l}\text { Plasti } \\
\text { k opp } \\
\text { besar }\end{array}$ & 480000 & 381837.6618 & 98162.33816 \\
\hline & & 41124850 & 29132382.23 & 11992467.77 \\
\hline
\end{tabular}

Penerapan jumlah pemesanan Tabel 12 yang ekonomis ternyata mempunyai total biaya persediaan lebih rendah yaitu sebesar $\mathrm{Rp}$ 29.132.382,23 (dibulatkan menjadi Rp.29.132.382) dibandingkan dengan kebijakan pengadaan persediaan bahan yang ditetapkan perusahaan yaitu sebesar Rp 41.124.850 sehingga dengan diterapkannya metode EOQ ini perusahaan akan dapat meminimalkan total biaya persediaan sebesar Rp 11.992.467 per tahun.

Perbedaan jumlah pemesanan per order yang ditetapkan dengan model EOQ dan kebijakan perusahaan berpengaruh pada berbedaan frekuensi pemesanan persediaan Tebel 13. 
Tabel 13. Perbandingan Frekuensi Pemeanan CV.Rafhanah

\begin{tabular}{clccc}
\hline No & \multicolumn{1}{c}{ Part } & $\begin{array}{c}\text { Kebijakan } \\
\text { Perusahaan }\end{array}$ & EOQ & Selisih \\
\hline 1 & Kain & 22 & 5 & 17 \\
2 & Bordir Logo kecil & 8 & 3 & 5 \\
3 & Reseleting & 9 & 2 & 7 \\
4 & Hantag hitam & 8 & 2 & 6 \\
5 & Label & 8 & 2 & 6 \\
6 & Plastik opp besar & 7 & 3 & 4 \\
\hline
\end{tabular}

Perbedaan frekuensi pemesanan persediaan antara model EOQ dan kebijakan perusahaan berpengaruh pada jumlah biaya pemesanan dan biaya penyimpanan yang harus ditanggung. Selain itu, frekuensi pemesanan juga mempengaruhi kelancaran proses produksi.

Hasil perbandingan menunjukkan bahwa dari sisi frekuensi pembelian bahan, biaya pesan, dan biaya simpan, perusahaan belum menerapkan efisiensi secara optimal. Hal ini dapat dilihat dari tabel-tabel pebandingan biaya kebijakan perusahaan dengan menggunakan metode EOQ yang terlihat jauh lebih rendah dibandingkan dengan kebijakan perusahaan.

Salah satu cara yang dapat ditempuh dalam pengelolaan persediaan untuk menekan pemborosan adalah dengan menerapkan metode EOQ dalam menentukan jumlah pembelian bahan. Kegiatan pengelolaan persediaan yang paling efisien membutuhkan kebijakan sebagai pedoman dalam melakukan tindakan. Ketidak tepatan kebijakan yang dirumuskan dapat menimbulkan ketidak efisienan. Semua komponen persediaan pada CV.Rafhanah dapat dihitung menggunakan model EOQ dikarenakan semua jenis komponen yang terdapat dalam produk tersebut dapat bertahan lama dan dapat disimpan dalam waktu yang lama.

\section{PENUTUP}

Berdasarkan hasil dan pembahasan dari penelitian yang dilakukan mengenai perbandingan efisiensi manajemen persediaan CV.Rafhanah dengan manajemen persediaan model EOQ, disimpulkan;

1. Total biaya persediaan yang harus dikeluarkan oleh CV.Rafhanah sebesar Rp 41.124 .850 sedangkan dengan hasil perhitungan EOQ, total biaya persediaan sebedar Rp. 29.132.382. Sehingga pada penerapan model EOQ biaya total persediaan menghasilkan penghematan biaya sebesar Rp 11.992.467.

2. Semua komponen persediaan pada CV.Rafhanah dapat dihitung menggunakan model EOQ dikarenakan semua jenis komponen yang terdapat dalam produk tersebut dapat bertahan lama dan dapat disimpan dalam waktu yang lama.

\section{UCAPAN TERIMA KASIH}

Terima kasih kepada UPNVJ Fakultas Teknik, Mahasiswa Teknik Industri 2017, terima kasih sebesarnya kepada Santika Sari, ST, MT.

\section{DAFTAR PUSTAKA}

Chung, Kun Jen, and Leopoldo Eduardo CárdenasBarrón. 2012. "The Complete Solution Procedure for the EOQ and EPQ Inventory Models with Linear and Fixed Backorder Costs." Mathematical and Computer Modelling 55(11-12):

2151-56. http://dx.doi.org/10.1016/j.mcm.2011.12.05 1.

Godichaud, Matthieu, and Lionel Amodeo. 2019. "EOQ Models with Stockouts for Disassembly Systems." IFAC-PapersOnLine 52(13): 168186.https://doi.org/10.1016/j.ifacol.2019.11.4 42.

Mishra, S. S., and P. P. Mishra. 2008. "Price Determination for an EOQ Model for Deteriorating Items under Perfect Competition." Computers and Mathematics with Applications 56(4): 1082-1101.

Naibaho, Alex Tarukdatu. "Analisis Pengendalian Internal Persediaan Bahan Baku Terhadap Efektifitas Pengelolaan Persediaan Bahan Baku."1(3):63-

70.https://media.neliti.com/media/publicati ons/1520-ID-analisis-pengendalian-internalpersediaan-bahan-baku-terhadap-efektifitaspengel.pdf.

Ng, C. T., T. C.E. Cheng, Vladimir Kotov, and Mikhail Y. Kovalyov. 2009. "The EOQ Problem with Decidable Warehouse Capacity: Analysis, Solution Approaches and Applications." Discrete Applied Mathematics 157(8): 180624.http://dx.doi.org/10.1016/j.dam.2009.01. 004.

Omar, M., M. Bakri Zubir, and N. H. Moin. 2010. "An Alternative Approach to Analyze Economic Ordering Quantity and Economic Production Quantity Inventory Problems Using the Completing the Square Method." Computers and Industrial Engineering 59(2): 362-64. http://dx.doi.org/10.1016/j.cie.2010.04.012.

Suryanto, Matius Rinto. 2012. "Efisiensi Penggunaan Model EOQ (Economic Order Quantity) Pada PT. Puspa Madu Salatiga." Among Makarti 5(10): 110-34. 